\title{
Changes in levels of BNP, CRP and leukocyte formula during exercise testing in patients with dilated cardiomyopathy
}

\author{
V Peric $^{1 *}$, A Jovanovic ${ }^{1}$, R Stolic ${ }^{1}$, S Sovtic ${ }^{1}$, M Sipic ${ }^{1}$, P Otasevic ${ }^{2}$ \\ From 23rd World Congress of the World Society of Cardio-Thoracic Surgeons \\ Split, Croatia. 12-15 September 2013
}

\section{Background}

So far, not enough clear change in biochemical parameters during exercise in patients with dilated cardiomyopathy (DCM). The aim of this paper is to study the value of BNP, CRP and leukocyte formula during exercise testing in patients with DCM.

\section{Methods}

The study included 55 consecutive patients with DCM. All patients underwent symptoms limited exercise testing according to the Bruce's protocol. Baseline, at peak test, and 12 months after the test to all patients blood was taken for determination of these biochemical parameters.

\section{Results}

During exercise testing have been increasing BNP (246.98 \pm 571.74 vs. $257.91 \pm 473.47 \mathrm{ng} / \mathrm{L}, \mathrm{p}=0.002)$, CRP $(3.83 \pm$ 5.04 vs. $4.14 \pm 5.25 \mathrm{mg} / \mathrm{L}, \mathrm{p}=0.016)$ and $\mathrm{WBC}$ count $(8.01 \pm 1.83$ vs. $10.61 \pm 2.54 \times 109 / \mathrm{L}, \mathrm{p}<0.001)$. Increased the number of neutrophils $(4.80 \pm 1.42$ vs. $5.85 \pm 1.89 \mathrm{x}$ $109 / \mathrm{L}, \mathrm{p}<0.001)$, lymphocytes $(2.30 \pm 0.72$ vs. $3.50 \pm 1.15 \mathrm{x}$ $109 / \mathrm{L}, \mathrm{p}<0.001)$, eosinophil $(0.20 \pm 0.16$ vs. $0.26 \pm 0.24 \mathrm{x}$ $109 / \mathrm{L}, \mathrm{p}<0.001)$, monocytes $(0.65 \pm 0.22$ vs. $0.88 \pm 0.29 \mathrm{x}$ $109 / \mathrm{L}, \mathrm{p}<0.001)$ and basophils $(0.01 \pm 0.04$ vs. $0.04 \pm 0.01$ $\mathrm{x} 109 / \mathrm{L}, \mathrm{p}<0.029)$. Twelve months after the exercise test found significantly higher BNP levels $(163.93 \pm 266.05$ vs. $279 \pm 416.58 \mathrm{ng} / \mathrm{L}, \mathrm{p}=0.002)$, whereas CRP $(3.93 \pm 5.28$ vs. $3.03 \pm 2.82 \mathrm{mg} / \mathrm{L})$ and WBC $(8.05 \pm 1.92$ vs. $7.84 \pm$ $1.81 \times 109 / \mathrm{L})$ did not change significantly in comparison to baseline values.
* Correspondence: pericvladan@yahoo.com

'University of Pristina, School of Medicine, Internal Clinic, Kosovska, Kosovo

Full list of author information is available at the end of the article

\section{Conclusions}

During exercise testing in patients with DCM there was a significant increase in the level of BNP, CRP, and all parameters of leukocyte formula.

\section{Authors' details}

'University of Pristina, School of Medicine, Internal Clinic, Kosovska, Kosovo. ${ }^{2}$ Dedinje Cardiovascular Institute, Belgrade, Serbia.

Published: 11 September 2013

doi:10.1186/1749-8090-8-S1-P24

Cite this article as: Peric et al:: Changes in levels of BNP, CRP and leukocyte formula during exercise testing in patients with dilated cardiomyopathy. Journal of Cardiothoracic Surgery 2013 8(Suppl 1):P24.

Submit your next manuscript to BioMed Central and take full advantage of:

- Convenient online submission

- Thorough peer review

- No space constraints or color figure charges

- Immediate publication on acceptance

- Inclusion in PubMed, CAS, Scopus and Google Scholar

- Research which is freely available for redistribution

Submit your manuscript at www.biomedcentral.com/submit 